\title{
Nitric oxide and membrane lipid peroxidation in photosynthetic and non-photosynthetic organisms under several stress conditions
}

\author{
Andrea Galatro, Paula M. González, Gabriela Malanga, Elizabeth Robello, Natacha E. Piloni and \\ Susana Puntarulo*
}

Physical Chemistry, School of Pharmacy and Biochemistry, Institute of Biochemistry and Molecular Medicine, University of Buenos Aires-CONICET, Buenos Aires, Argentina

${ }^{*}$ Correspondence: susanap@ffyb.uba.ar

Edited by:

Angel Catala, Universidad Nacional de La Plata, Argentina

Reviewed by:

Alexi Alekov, Medizinische Hochschule Hannover, Germany

Keywords: nitric oxide, lipid peroxidation, photosynthetic organisms, animals, oxidative stress conditions

\section{INTRODUCTION}

Oxidative damage to lipids was characterized in terms of the nature of the oxidant, the type of lipid, and the severity of the oxidation (Simontacchi et al., 2011). Even though malondialdehyde detection with the thiobarbituric acid reactive substances test (TBARS) is the most currently used assay for the determination of lipid oxidation, it is unspecific since the reaction can be reproduced by other biological compounds (Simontacchi et al., 2011). On the other hand, electron paramagnetic resonance (EPR) spectroscopy showed the capacity of detecting the presence of the lipid radicals $\left(\mathrm{LR}^{\bullet}\right)$ formed during peroxidation, by yielding unique and stable products with spin traps (Malanga and Puntarulo, 2012). Nitric oxide (NO) is recognized both, as a signaling molecule that regulates many enzyme activities, but as a toxic agent as well. It has been found that $\mathrm{NO}$ is able to protect animal and plant cell types from oxidative damage resulting from superoxide $\left(\mathrm{O}_{2}^{-}\right)$, hydrogen peroxide $\left(\mathrm{H}_{2} \mathrm{O}_{2}\right)$ and alkyl peroxides by acting as a terminator of free radical chain reactions (Wink et al., 1995, 1996; Yalowich et al., 1999; Beligni and Lamattina, 2002; Sharpe et al., 2003). Reactive oxygen species (ROS) and reactive nitrogen species (RNS) interact through the reaction of $\mathrm{O}_{2}^{-}$with $\mathrm{NO}$, to generate peroxynitrite $\left(\mathrm{ONOO}^{-}\right)$at a rate close to diffusion. $\mathrm{ONOO}^{-}$acts as both, a nitrating agent and a powerful oxidant capable of modifying proteins (formation of nitrotyrosine), lipids (lipid oxidation, lipid nitration), and nucleic acids (DNA oxidation and DNA nitration) (Gisone et al., 2004).

The purpose of this commentary is to point out that NO complex interactions with other cellular components lead to a wide range of effects depending on the biological system under study and the oxidative stress condition.

\section{LIPID PEROXIDATION AND NO IN PHOTOSYNTHETIC ORGANISMS}

In cultures of the green algae Chlorella vulgaris no significant changes were observed in either of the parameters showed in Table $\mathbf{1}$, in the stationary phase as compared to the log phase of growth. However, Qian et al. (2009) demonstrated in Chlorella vulgaris that, depending on its concentration, NO increased the activity of antioxidant enzymes to protect against the oxidative damage caused by herbicide stress. Data from Simontachi et al. (2004) showed that the NO steady state concentration in homogenates from sorghum embryonic axes reached a maximum at 24-30 $\mathrm{h}$ after the starting of imbibition, in coincidence with the initiation of an active germination. The generation of $\mathrm{LR}^{\bullet}$ in sorghum axes was drastically increased at $36 \mathrm{~h}$ of imbibition from non-detectable values at $24 \mathrm{~h}$, coincidentally with the significant decline in the content of cellular NO (Table 1).

To analyze the role of NO during senescence, Jasid et al. (2009) sprayed daily soybean cotyledons with an NO donor solution (sodium nitroprusside, SNP), from day 5 to 25. Differently from naturally senescent cotyledons, where NO content reached a maximum at day 10 of seedling development and declined, in SNP-treated cotyledons NO content was higher, and remained unchanged from day 10 to 25 after germination, as compared to control values. While naturally senescent cotyledons experimented no change in the content of $\mathrm{LR}^{\bullet}$ during the studied period, SNP-treated cotyledons showed a decrease as time progressed (Table $\mathbf{1}$ ).

Shi et al. (2005) suggested that the protective effect of $\mathrm{NO}$ on the oxidative damage of thylakoid membrane proteins in Phaseolus vulgaris beans under UV-B radiation may be mediated by increasing the level of expression of genes encoding ROS-scavenging enzymes. Moreover, Jasid et al. (2006) showed that isolated chloroplasts from soybean leaves exposed to $2 \mu \mathrm{M} \mathrm{NO}$ for $30 \mathrm{~min}$, decreased the rate of $\mathrm{LR}^{\bullet}$ generation (Table 1 ). Also, Jasid et al. (2008) reported that axes from sorghum seeds incubated $24 \mathrm{~h}$ in the presence of SNP, showed a significantly higher NO content as compared to control axes, and $\mathrm{LR}^{\bullet}$ content evaluated in the microsomal fractions was significantly lower, as compared to control membranes (Table 1).

\section{LIPID PEROXIDATION AND NO IN NON-PHOTOSYNTHETIC ORGANISMS}

Data in Table 1 show that seasonality affects oxidative metabolism in digestive glands (DG) from Nacella magellanica limpets isolated from the Beagle Channel, Tierra del Fuego, Argentina. A significant increase in both $\mathrm{LR}^{\bullet}$ and $\mathrm{NO}$ content in summer, as compared to winter, 
Table 1 | Nitric oxide and lipid peroxidation under stress conditions in photosynthetic and non-photosynthetic organisms.

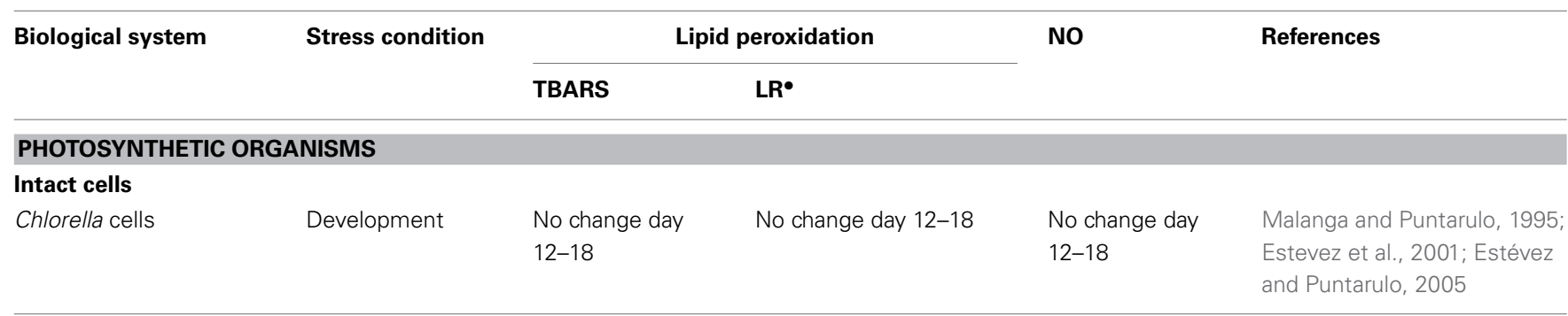

\section{Homogenates}

Sorghum embryonic axes Development nd

Soybean cotyledons Senescence nd

+ SNP nd

nd $\quad$ Increased from 36 to 48

nd $\quad$ No change day 10-25

d

\section{Decreased from Simontachi et al., 2004 \\ 36 to $48 \mathrm{~h}$}

Non-detectable at Jasid et al., 2009

day 25

Decrease $58 \%$ day $10-25 \quad$ No change day

$10-25$

\begin{tabular}{|c|c|c|c|c|c|}
\hline \multicolumn{6}{|l|}{ Sub-cellular structures } \\
\hline $\begin{array}{l}\text { Chloroplasts from } \\
\text { soybean leaves }\end{array}$ & + GSNO $250 \mu \mathrm{M}$ & nd & Decrease $29 \%$ & $\begin{array}{l}2 \mu \mathrm{M} N O \text { (supple- } \\
\text { mentation) }\end{array}$ & Jasid et al., 2006 \\
\hline $\begin{array}{l}\text { Microsomes from } \\
\text { sorghum embryonic axes }\end{array}$ & +SNP $1 \mathrm{mM}$ & nd & Decrease $43 \%$ & Increase $140 \%$ & Jasid et al., 2008 \\
\hline \multicolumn{6}{|c|}{ NON-PHOTOSYNTHETIC ORGANISMS } \\
\hline \multicolumn{6}{|l|}{ Invertebrates } \\
\hline \multicolumn{6}{|l|}{ Mammals } \\
\hline \multirow[t]{2}{*}{ Fetus rat brain } & $\gamma$ radiation $2 \mathrm{~h}$ & No change & No change & 6-fold increase & Gisone et al., 2003 \\
\hline & $\gamma$ radiation $4 \mathrm{~h}$ & Increase $51 \%$ & nd & No change & Gisone et al., 2003 \\
\hline Rat liver & $\mathrm{Fe} 500 \mathrm{mg} / \mathrm{kg}$ & 2.7-fold increase & nd & No change & $\begin{array}{l}\text { Galleano and Puntarulo, 1992; } \\
\text { Rousseau et al., } 2011\end{array}$ \\
\hline
\end{tabular}

nd stands for non-determined.

was reported (Malanga et al., 2007). However, studies on toxicological effects of $\mathrm{Fe}$ exposure under laboratory conditions showed that significant increases in lipid peroxidation were temporarily associated to decreases in $\mathrm{NO}$ content in DG from the bivalve Mya arenaria after 17 days of treatment (González et al., 2010) (Table 1).

In vivo $\gamma$ irradiation of rat fetuses did not significantly affect neither the content of $\mathrm{LR}^{\bullet}$ nor the content of TBARS in the brain up to $2 \mathrm{~h}$ post-irradiation (pi). However, $4 \mathrm{~h}$ after the exposure, a significant increase in the TBARS content was measured. These results are consistent with the hypothesis that changes could be produced in the brain at the early stages after exposure to $\gamma$ radiation to limit free radical-dependent damage, since increased lipid peroxidation was only detected after $4 \mathrm{~h}$ pi. Gisone et al. (2003) showed that total NO synthase activity was increased after 30 and $60 \mathrm{~min} \mathrm{pi,} \mathrm{and}$ returned to control values after $2 \mathrm{~h}$ pi, and accordingly NO content was significantly increased (Table 1).

Galleano and Puntarulo (1992) showed that liver homogenates from Fe-dextran overloaded male Wistar rats showed a significant increase in TBARS $6 \mathrm{~h}$ postinjection, as compared to control rats (Table 1). Later, Galleano et al. (2001) pointed out that the significant increase in $\mathrm{NO}$, assayed as $\mathrm{DETC}_{2}-\mathrm{Fe}-\mathrm{NO}$ adducts $5 \mathrm{~h}$ after $\mathrm{Fe}$ administration could be an artifact due to the excess of Fe during the measurement. Recently, Rousseau et al. (2011) showed that one of the molecular footprints left by the reactions of ROS with biomolecules, the level of protein 3-nitrotyrosines, was not increased by
Fe-dextran administration, suggesting that $\mathrm{Fe}$ overload in liver did not change NO cellular content (Table 1).

\section{CONCLUDING REMARKS}

The results summarized here implied the existence of a very complex regulatory interplay between $\mathrm{NO}$ and ROS. The multiple effects of $\mathrm{NO}$ on the process of lipid peroxidation imply that the net result will depend on the balance of competing factors. The rate and location of $\mathrm{NO}$ formation, and also the rate of formation of $\mathrm{O}_{2}^{-}$, or other mitigating factors, will all contribute to the degree and the nature of the effect on lipid oxidation in a particular system. Detailed analysis of the molecular mechanisms in each condition is required. In this regard, no yet deeply studied NO reactions, such as NO binding to $\mathrm{Fe}$ and 
endogenous thiols and other nitrosyl-Fe complexes that seems to favor Fe release from the cell avoiding its accumulation, could reveal to be a key factor in NO cellular interactions and should be further characterized.

\section{ACKNOWLEDGMENTS}

This study was supported by grants from the University of Buenos Aires, ANPCyT and CONICET to Susana Puntarulo. Susana Puntarulo, Gabriela Malanga, and Andrea Galatro are career investigator from CONICET, and Paula M. González and Natacha Piloni are fellows from CONICET.

\section{REFERENCES}

Beligni, M. V., and Lamattina, L. (2002). Nitric oxide interferes with plant photo-oxidative stress by detoxifying reactive oxygen species. Plant Cell Environ. 25, 737-748. doi: 10.1046/j.13653040.2002.00857.x

Estevez, M. S., Malanga, G., and Puntarulo, S. (2001). Iron-dependent oxidative stress in Chlorella vulgaris. Plant Sci. 161, 9-17. doi: 10.1016/S01689452(01)00364-8

Estévez, S., and Puntarulo, S. (2005). Nitric oxide generation upon growth of Antarctic Chlorella sp. cells. Physiol. Plantarum 125, 192-201. doi: 10.1111/j.1399-3054.2005.00561.x

Galleano, M., Aimo, L., Borroni, M. V., and Puntarulo, S. (2001). Nitric oxide and iron overload. Limitations or ESR detection by DETC. Toxicology 167, 199-205. doi: 10.1016/S0300483X(01)00474-7

Galleano, M., and Puntarulo, S. (1992). Hepatic chemiluminescence and lipid peroxidation in mild iron overload. Toxicology 76, 27-38. doi: 10.1016/0300-483X(92)90015-7

Gisone, P., Boveris, A. D., Dubner, D., Perez, M. R., Robello, E., and Puntarulo, S. (2003). Early neuroprotective effect of nitric oxide in developing rat brain irradiated in utero. Neurotoxicology $24,245-253$. doi: 10.1016/S0161-813X(02) 00166-3

Gisone, P., Dubner, D., Pérez, M. R., Michelin, S., and Puntarulo, S. (2004). The role of nitric oxide in the radiation-induced effects in the developing brain. In Vivo 18, 281-292.
González, P. M., Abele, D., and Puntarulo, S. (2010). Exposure to excess dissolved iron in vivo affects oxidative status in the bivalve Mya arenaria. Comp. Biochem. Physiol. C 152, 167-174. doi: 10.1016/j.cbpc.2010.04.006

Jasid, S., Galatro, A., Villordo, J. J., Puntarulo, S., and Simontacchi, M. (2009). Role of nitric oxide in soybean cotyledon senescence. Plant Sci. 176, 662-668. doi: 10.1016/j.plantsci.2009. 02.007

Jasid, S., Simontacchi, M., Bartoli, C. G., and Puntarulo, S. (2006). Chloroplasts as a nitric oxide cellular source. Effect of reactive nitrogen species on chloroplastic lipids and proteins. Plant Physiol. 142, 1246-1255. doi: 10.1104/pp.106.086918

Jasid, S., Simontacchi, M., and Puntarulo, S. (2008). Exposure to nitric oxide protects against oxidative damage but increases the labile iron pool in sorghum embryonic axes. J. Exp. Bot. 59, 3953-3962. doi: 10.1093/jxb/ern235

Malanga, G., Estevez, S., Calvo, J., Abele, D., and Puntarulo, S. (2007). Seasonality effect on oxidative metabolism in Nacella (P.) magellanica. Comp. Biochem. Physiol. A 146, 551-558. doi: 10.1016/j.cbpa.2006.01.029

Malanga, G., and Puntarulo, S. (1995). Oxidative stress and antioxidant content in Chlorella vulgaris after exposure to ultraviolet-B radiation. Physiol. Plantarum 94, 672-679. doi: 10.1111/j.1399. 3054.1995.tb00983.x

Malanga, G., and Puntarulo, S. (2012). "The use of electron paramagnetic resonance (EPR) in the study of oxidative damage to lipids in aquatic systems," in Book on Oxidative Stress in Aquatic Ecosystems, eds D. Abele, T. ZentenoSavín, and J. P. Vázquez-Medina (Oxford, UK: Willey-Blackwell), 448-457.

Qian, H., Chen, W., Li, J., Wang, J., Zhou, Z., Liu, W., et al. (2009). The effect of exogenous nitric oxide on alleviating herbicide damage in Chlorella vulgaris. Aquat. Toxicol. 92, 250-257. doi: 10.1016/j.aquatox.2009.02.008

Rousseau, I., Galleano, M., and Puntarulo, S. (2011). Fe allocation in liver during early stages of endotoxemia in Fe-overload rats. Toxicol. Pathol. 39, 1075-1083. doi: 10.1177/0192623311425057

Sharpe, M. A., Robb, S. J., and Clark, J. B. (2003). Nitric oxide and Fenton/Haber-Weiss chemistry: nitric oxide is a potent antioxidant at physiological concentrations. J. Neurochem. 87, 386-394. doi: 10.1046/j.1471-4159.2003.02001.x

Shi, S., Wang, G., Wang, Y., Zhang, L., and Zhang, L. (2005). Protective effect of nitric oxide against oxidative stress under ultraviolet-B radiation.
Nitric Oxide 13, 1-9. doi: 10.1016/j.niox.2005. 04.006

Simontacchi, M., Buet, A., and Puntarulo, S. (2011). "The use of electron paramagnetic resonance (EPR) in the study of oxidative damage to lipids in plants," in Lipid Peroxidation: Biological Implications, ed A. Catalá (Kerala, India: Res. Signpost Transworld Res. Network), 141-160. ISBN: 978-81-7895-527-8

Simontachi, M., Jasid, S., and Puntarulo, S. (2004). Nitric oxide generation during early germination of sorghum seeds. Plant Sci. 167, 839-847. doi: 10.1016/j.plantsci.2004.05.028

Wink, D. A., Cook, J. A., Pacelli, R., Degraff, W., Gamson, J., Liebmann, J., et al. (1996). The effect of various nitric oxide-donor agents on hydrogen peroxide-mediated toxicity: a direct correlation between nitric oxide formation and protection. Arch. Biochem. Biophys. 331, 241-248. doi: 10.1006/abbi.1996.0304

Wink, D. A., Cook, J. A., Pacelli, R., Liebmann, J., Krishna, M. C., and Mitchell, J. B. (1995) Nitric oxide (NO) protects against cellular damage by reactive oxygen species. Toxicol. Lett. 82/83, 221-226. doi: 10.1016/0378-4274(95)03557-5

Yalowich, J. C., Conery, A., Thampatty, P., Allan, W. P., Baskaran, R., and Bhalla, K. N. (1999). Sensitization of $\mathrm{BCR}-\mathrm{ABL}^{+}$cells to etoposide (VP-16) induced apoptosis: use of the tyrosine kinase inhibitor CGP57148B (Abstract). Proc. Am. Assoc. Cancer Res. 40, 4866.

Received: 15 July 2013; accepted: 13 September 2013; published online: 17 October 2013.

Citation: Galatro A, González PM, Malanga G, Robello E, Piloni NE and Puntarulo $S$ (2013) Nitric oxide and membrane lipid peroxidation in photosynthetic and non-photosynthetic organisms under several stress conditions. Front. Physiol. 4:276. doi: 10.3389/fphys. 2013.00276

This article was submitted to Membrane Physiology and Membrane Biophysics, a section of the journal Frontiers in Physiology.

Copyright (C) 2013 Galatro, González, Malanga, Robello, Piloni and Puntarulo. This is an open-access article distributed under the terms of the Creative Commons Attribution License (CC BY). The use, distribution or reproduction in other forums is permitted, provided the original author(s) or licensor are credited and that the original publication in this journal is cited, in accordance with accepted academic practice. No use, distribution or reproduction is permitted which does not comply with these terms. 